\title{
Exploring STEAM teaching in preschool using Fred Rogers approach
}

\author{
Zahiroh Awang, Nooraida Yakob, Aswati Hamzah, Mohd Mernan Talling
}

School of Educational Studies, Universiti Sains Malaysia, Malaysia

\begin{tabular}{l} 
Article Info \\
\hline Article history: \\
Received Apr 17, 2020 \\
Revised Sep 13, 2020 \\
Accepted Oct 10, 2020 \\
\hline Keywords: \\
Fred Rogers' STEAM \\
Need analysis \\
Preschool education \\
STEAM teaching
\end{tabular}

\section{Corresponding Author:}

Zahiroh Awang,

School of Educational Studies,

Universiti Sains Malaysia,

11800 Penang, Malaysia.

Email: merza2407@gmail.com

\begin{abstract}
The culture of Science, Technology, Engineering, Art and Mathematics (STEAM) teaching is still new among preschool teachers. Nevertheless, STEAM teaching is seen as challenging to be implemented if there is no clear guideline prepared by qualified experts. Therefore, a need analysis on STEAM teaching strategies ought to be conducted to ensure the implementation of STEAM teaching its related problems may be attended. This research aimed to explore experts' perceptions about Fred Rogers' STEAM as a STEAM teaching strategy approach as a considered method to be taught in preschools. This need analysis employed semi structured interviews with four experts. The obtained findings were categorized and analysed thematically. Five themes were identified: 1) features and needs of STEAM education, 2) inquiry-based learning 3) learning by doing activities, 4) interesting and systematic teaching strategies and 5) suitability with children' development and practices. The research findings benefit preschool teachers in selecting and implementing STEAM teaching strategies based on experts' opinion. Besides, it is anticipated to help teachers to conduct meaningful and effective STEAM teaching with preschool children.
\end{abstract}

This is an open access article under the CC BY-SA license.

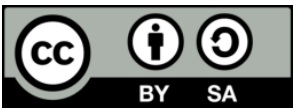

\section{INTRODUCTION}

Ministry of Education (MOE) Malaysia has outlined the need of Science, Technology, Engineering and Mathematics or STEM to students from the early stage schooling or preschools [1]. The demands of STEM field alert policymakers and educators to equip students with the changing workforce and the technology-driven future [2]. The development of 21st-century education is believed to be able to bring the aim of STEM Education into reality. In fact, it is able to produce a creative STEM innovator who is able to chart an excellent future of the country.

Stakeholders in Malaysia starts to highlight the importance of STEM Education since Malaysia facing problem with students' enrolment in science stream. Based on [3], the 60:40 (science: arts) policy until now has not been achieved. Thus, a solution is needed to ensure STEM can be implemented in an interesting way. Several scholars have identified that integrating arts element in STEM brings about fun learning especially in the context of preschool education $[4,5]$. Children are believed to have built-in art elements within them. With arts, they are allowed to share ideas through social activities, language arts, fine arts, music and creative movements $[4,6]$. 
According to Edwards [7], visual art is a component out of five art components which include; (a) literature, (b) drama, (c) music, (d) dance and (e) visual arts. Visual arts have the potential to increase students' cognitive abilities to learn STEM. Children express their feelings and thinking through visual art activities by creating two-dimensional visual work like drawing, painting and printing, and as a result, the three-dimensional artwork like creating a model, sculpture and building would be produced [7]. Actually, arts would help children think and understand life in creative ways $[4,5,8]$. Therefore, the need for integrating arts in STEM is vital [4, 9-12]. With arts, children become more likely understanding STEM [13, 14]. This is because they akin to build, draw and create something as to record their own learning experiences. Arts enable them to easily understand and express various STEM concept ideas through possible activities such as blocks building, clay manipulating, dramatic games, drawing and dancing [15].

Usually, in a preschool class, it has a lot of art materials and tools ant this may support STEM initiative in preschool classes. Nevertheless, preschool children need to be allocated extended time as they need to explore the learning materials so as to build their creativity characters [16]. Art activities allow them to be imaginative and creative besides helping them to enhance their skills of space and perspective. Actually, children imaginative and creative could be developed when they are allowed to explore their learning materials freely. Katz [5], pointed out that limitless exploration may promote engineering skills, in which children might use the technology to create innovation. These skills were necessary skills for engineers and scientists for the country's technology development in the future.

Therefore, Sharapan [4] has proposed a new concept of STEM, the integration of A (Arts) which is known as STEAM. In the context of preschools, the meaning of STEAM is a process of teaching Science (S) that integrates the elements of Technology, Engineering, Art and Mathematics (STEAM). STEAM enables children to learn the importance of arts as a process of inventing products related to Science, Technology, Engineering and Mathematics. STEAM prepared many possible ways for children to be creative in real-world experiences. Children are given the opportunities to discover, explore, ask and create using Science and Mathematics via STEAM. Besides, children could enhance their 21st skills when arts are integrated into STEM as a way of communicating and presenting Engineering and Technology [15]. It also gives advantages to teachers since the integration of arts in STEM, could enhance teachers' experiences and skills related to engineering and technology.

Of this effort, teachers need to employ STEAM at the early stage that is from the preschool stage using two aspects: learning materials and environments [15]. The first aspect, learning materials, the use of materials needs to be appropriated with the children' growth and the second aspect, learning environments, the preparation of a learning environment must be meaningful to the children. Thus, as preschool teachers, they need to use varieties of materials to instil children skills in Science, Mathematics and Engineering. Nonetheless, the most important is the teachers' ability to deliver meaningful learning experiences to children by allowing them the opportunities in utilizing the materials maximumly.

Gordon and Browne [16] explained that the learning environment which is suitable for children need to have three main aspects: (a) time, (b) interpersonal and (c) physical space. These three aspects were essential to be taken into consideration when developing the basic STEAM among the children. The first aspect, the time for children to invent is very important. Children need a longer time to invent something. Children' learning time is not structured and flexible. They need to be encouraged to make decisions about play activities and tasks during their free activities. Second, the interpersonal community need to be considered when setting an environment that would promote STEAM in preschools. Hence, preschool teachers need to integrate discover and exploration situation in a learning environment to ensure the enhancement of children's 4Cs skills: communication, collaboration, creativity and critical thinking.

Thus, teachers will act as an expert that would be able to explain activities and assist children during their exploration and investigation. Teachers may ask open-ended and closed-ended questions to the children in order to trigger children's thinking. With these types of questions, children start to think critically regarding their world and inventions. Good questions may not only require one answer and giving an answer is not a priority to fulfil. Therefore, teachers need to allow children to explore their own learning. They need to encourage children to participate actively in meaningful discussions and develop children' thinking ability by asking provoking questions. This is very crucial as to let children experience their self-worth where communication is valued and mistakes are allowed.

The third aspect is the physical environment. The physical environment needs to be adjusted based on children's interests and needs. Teachers need to maximize the available physical environment for children to be exposed to various learning materials related to the real world on a daily basis. For instance, teachers may place a whiteboard, paper and writing tools such as pencils at the learning centre in order to encourage children to plan, draw, observe and label about chosen objects. Besides, teachers also need to provide access to related resources such as meaningful books, pictures and websites which are related to certain topics. This situation will enhance children's thinking ability regarding their world around them. 
In brief, the STEAM teaching implementation process required teachers' commitment and attention. It is very critical that teachers need to master the STEAM pedagogical knowledge to ensure the STEAM teaching process effectively. Therefore, it is believed that teachers should be equipped with STEAM guideline in order to meet the aspiration of the Malaysian Education Development Plan 2013-2025. For that reason, we proposed a systematic guideline of STEAM implementation using Fred Rogers' STEAM approach [4].

\section{LITERATURE REVIEW}

The concept of Fred Rogers' STEAM is about thinking capacity through questioning and investigating [4]. Fred Rogers' STEAM applies inquiry-based learning so that children are moulded to be a constructor of knowledge and theory. They guide their own learning through questions they ask and discover their own answer. They share and respond to what they learn and master their learning according to their development levels beginning from remembering to inventing. The children learn to collect, criticize, analyse and interpret information, create working theories, construct new questions, justify evidence and integrate new ideas through inquiry-based learning. Inquiry-based learning is essential in putting STEAM Education at the next level [2].

STEAM is encountered by children as they learn to know and understand the world and when interacting with their surroundings [17]. Children are exposed to a real-world environment to stimulate their inquisitiveness about life. They are given opportunities to explore and investigate using their own senses $[4,5]$. This activity allows them to collect, arrange, observe, note, sketch, interview and review anything related to certain topics or incidents. STEAM encourages children to stimulate the thinking process as they need to inquire questions and find a variety of answers in solving the problems [4].

According to [4], the first letter that is the letter $S$ in the abbreviation STEAM stands for Science. Science exposes children to scientific investigation activities. Children act as investigators who collect information related to their everyday living experience. They use their senses to observe, form questions, predict, investigate and discuss their findings. Science may be optimally applied through investigating the living world, physical world and material world [18].

Second, T stands for Technology. Technology refers to any object invented by human beings. Technology to children is related to tools or objects that are usable for investigations. The interaction between technological tools and children may enhance their cognitive development. Children learn about functions, reasons and consequences of using technological tools throughout their lives. Third, E refers to Engineering. Children are natural engineers. They learn to identify problems and seek for initiative solutions to solve problems according to their own creativity. For example, children learn to build a strong house model using blocks (lego). They learn to make the house base, walls, beams, roof, windows and doors and finally, they combine all the structures to build a house model.

Fourth, the letter A resembles the word Art. Art is a form of sensory exploration and it is active in children. Every child possesses the Art characteristic which may be used to interpret any situation using symbols as to resemble the real objects, events or feelings. Drawing, role-playing, music and dancing are media for children to express their creative characters. The last letter or the letter M stands for Mathematics. Children explore Mathematics through identifying quantity large or small, shapes, sizes, sequence and distance of objects. Activities such as identifying similarities and differences, sequencing, measuring and calculating are examples of high order thinking skills in Mathematics which may be instilled in children.

The STEAM integrated teaching as postulated by Fred Rogers is executed through three main steps 1) STEAM language conversation, 2) Finding STEAM everywhere, and 3) STEAM in the future [4]. In the first step is executing active STEAM language conversations with children every day. This activity may be conducted through puppet storytelling, animation, singing and storybooks. The conversations between teachers and children would expand the children' vocabulary and existing knowledge related to Science, Technology, Engineering, Art and Mathematics. This step is very important since it will stimulate children's interest in related STEAM topics.

In the second step, finding STEAM everywhere, it requires teachers to guide children to act as STEAM investigators. Fred Rogers (as cited in [4]) conducts activities of finding STEAM everywhere. This step is essential in order to ensure the introduced STEAM topic can be investigated and researched upon indepth. Therefore, teachers need to prepare an authentic environment to trigger children' inquisitiveness so that they are able to learn better. Appropriate tools, materials and media related to the STEAM topic are exposed to children in order to excite the children in natural ways. The interaction that occurs between children and the tools is expected to enable children to make new discoveries which then trigger inquiries in their minds. Such experiences and discoveries make children become more confident to ask questions and express their opinions pertaining to the activities conducted. STEAM experts are individuals who are responsible for helping children in handling various answers for the questions inquired. With the guidance 
provided by the STEAM experts, children are able to meaningfully engage in the learning process. This meaningful learning may hence inculcate interest and basic knowledge of STEAM amongst the children.

The third step is known as STEAM in the future. The objective of this step is to enhance children' interest in becoming a STEAM inventor in the future. Therefore, children will expose to the processes of problem identification and solution invention through a STEAM project. This project is the final activity to reinforce children' understanding of STEAM knowledge which has been explored in steps one and two.

Malaysia, in its pace towards becoming a developed country, has begun focusing on STEAM Education in order to enhance the field of STEM Education which has been earlier implemented since the last few years [19]. In line with the effort, STEAM Education has been rendered to teachers so as to make them aware of its importance [19]. However, despite having the awareness, the teachers' confidence level in executing STEAM Education in their classrooms is still low [20, 21]. This is probably due to a lack of understanding of the STEAM concept among the teachers, especially of preschool stage [4, 22, 23].

This may be due to limited evidence and resources on STEAM conceptualisation that can be referred to by teachers $[20,21,24,25]$. Cook [26] admits that teachers are not equipped with a complete guideline on teaching STEAM. Hence, teachers may not be able to understand clearly the concept of STEAM and this results in difficulty in STEAM pedagogical practices. In line with this, teachers, too are still challenged to master STEAM pedagogical knowledge [22-24].

With the addition of Art element in STEM, it is discovered that STEM knowledge may be delivered to children in a fun way. STEM concepts can be conveyed to children through art activities like singing, dancing, drawing and storytelling. Nevertheless, even though STEAM Education allows teachers to deliver STEAM education in various creative ways, there are still many teachers who are unable to execute STEAM teaching well [20-23, 25]. This may be the result of insufficient learning materials that may be referred to by teachers. This lack of resources has possibly caused drawbacks in STEAM teaching among teachers.

\section{RESEARCH OBJECTIVES}

This paper aims at exploring STEAM teaching strategy that is appropriate to be practised by preschool teachers. This research proposes Fred Rogers' approach as one of the 21st-century teaching strategies to be learnt and practised by preschool teachers in order to enhance their STEAM pedagogical knowledge [4]. Referring to Table 1, teachers can systematically and easily execute STEAM teaching activities.

Table 1. Fred Rogers' STEAM [4]

\begin{tabular}{|c|c|c|c|}
\hline Steps & & STEAM Teaching Activities & Explanation \\
\hline $\begin{array}{l}\text { 1. STEAM } \\
\text { language } \\
\text { conversation }\end{array}$ & 1.1 & $\begin{array}{l}\text { Practising STEAM language } \\
\text { conversation every day }\end{array}$ & $\begin{array}{l}\text { Active conversation practice between teachers and children } \\
\text { regarding their existing knowledge on certain topics. For example, } \\
\text { discuss a butterfly life which includes size, color, shape, movement, } \\
\text { food and living period (all are related to the STEAM concept). }\end{array}$ \\
\hline \multirow{5}{*}{$\begin{array}{l}\text { 2. Finding } \\
\text { STEAM } \\
\text { everywhere }\end{array}$} & 2.1 & $\begin{array}{l}\text { Building while exploring the } \\
\text { surrounding }\end{array}$ & $\begin{array}{l}\text { This activity promotes inquisitiveness in children about a butterfly } \\
\text { through singing, video, picture cards, eBook, encyclopedia and } \\
\text { others. }\end{array}$ \\
\hline & 2.2 & $\begin{array}{l}\text { Expanding children' natural } \\
\text { interest }\end{array}$ & $\begin{array}{l}\text { An activity to expand children' natural interest in a butterfly. For } \\
\text { example, investigating the natural life cycle of a butterfly in a } \\
\text { butterfly farm. }\end{array}$ \\
\hline & 2.3 & $\begin{array}{l}\text { Encouraging and appreciating } \\
\text { students' questions }\end{array}$ & $\begin{array}{l}\text { An activity to encourage children to ask questions seek answers and } \\
\text { solutions to the problems. }\end{array}$ \\
\hline & 2.4 & Inviting STEAM Experts & $\begin{array}{l}\text { An activity conducted with experts who may share information and } \\
\text { experience related to the researched topic in STEAM teaching. }\end{array}$ \\
\hline & 2.5 & $\begin{array}{l}\text { Creating meaningful } \\
\text { atmosphere }\end{array}$ & $\begin{array}{l}\text { An in-depth scientific investigation on butterflies with guidance } \\
\text { from the experts and teachers. For instance, investigating the use of } \\
\text { magnet in moving the butterfly model. }\end{array}$ \\
\hline \multirow{3}{*}{$\begin{array}{l}\text { 3. STEAM in } \\
\text { the future }\end{array}$} & 3.1 & Current STEAM Perspective & $\begin{array}{l}\text { An activity to recognize children' knowledge to solve problems. } \\
\text { For example, the limited space for butterflies to reproduce in the } \\
\text { urban area. }\end{array}$ \\
\hline & 3.2 & STEAM Technology Inventor & $\begin{array}{l}\text { An activity to make children a creative inventor of STEAM } \\
\text { Technology. For instance, making a butterfly cage. }\end{array}$ \\
\hline & 3.3 & $\begin{array}{l}\text { Presenting STEAM Technology } \\
\text { Work }\end{array}$ & $\begin{array}{l}\text { An activity to encourage children to communicate and deliver } \\
\text { information based on their own experiences as they become } \\
\text { STEAM Technology inventor. }\end{array}$ \\
\hline
\end{tabular}

Int. J. Eval. \& Res. Educ. Vol. 9, No. 4, December 2020: 1071 - 1078 


\section{RESEARCH METHOD}

This research conducted using a qualitative design aiming at exploring experts' perceptions of Fred Rogers' approach as an appropriate STEAM teaching strategy in preschools. It involved four experts as the research informants. Two of the experts were servicing in the field of STEAM Education in the Institute of Teacher Education, Malaysia. The third expert was from the Curriculum Development Department, Ministry of Education Malaysia and the fourth one was from a local university. Both the third and the fourth experts were identified to have expertise in the field of preschool education. All the experts were selected purposively as the selection was made based on their expertise in STEAM Education, particularly at the preschool level. The details of the experts are summarised in Table 2.

Table 2. Details of experts

\begin{tabular}{|c|c|c|c|c|c|}
\hline No. & Position & Gender & Field & Place of service & Experience \\
\hline 1 & Lecturer & Female & STEAM Education & Institute of Teacher Education, Malaysia & 23 years \\
\hline 2 & Lecturer & Male & STEAM Education & Institute of Teacher Education, Malaysia & 23 years \\
\hline 3 & Curriculum developer & Male & Preschool Education & Curriculum Development Department, MOE & 13 years \\
\hline
\end{tabular}

The data were collected through semi-structured interviews (which took approximately two hours for each expert). The researcher developed a set of an instrument on Experts' Needs Analysis which had been earlier adapted from Needs Analysis Instrument by Yaakob [27] to be used throughout the interview sessions. The details of the data collection execution are as seen in Table 3.

Table 3. Executions of expert interviews

\begin{tabular}{cccc}
\hline No. & Date of interview & Time of interview & Place of interview \\
\hline Expert 1 & 05 July 2018 & 09.00 a.m. -11.00 a.m. & IPG Teknik Kampus Bandar Enstek Nilai Negeri Sembilan \\
Expert 2 & 05 July 2018 & 02.30 p.m. -04.30 p.m. & IPG Teknik Kampus Bandar Enstek Nilai Negeri Sembilan \\
Expert 3 & 14 May 2018 & 02.00 p.m.-04.00 p.m. & Curriculum Development Department, MOE \\
Expert 4 & 08 May 2018 & 11.30 a.m.-01.30 p.m. & Universiti Pendidikan Sultan Idris \\
\hline
\end{tabular}

The qualitative data obtained from the interviews were analysed thematically in line with the research question 'To what extent Fred Rogers' Approach is appropriate for preschool STEAM teaching?' First, the data were transcribed, recorded and reduced in order to answer the research question. The process of data reduction included selecting, focusing, simplifying and transforming the obtained data from the transcript. After the reduction process, the researcher extracted the needed data and made conclusions as well as verification [28]. Verifying the data is very essential in ensuring their quality as the researcher attempted to meet the objective of the study. The interview data obtained was reviewed and verification with the past studies findings, the Ministery of Education annual report, and the curriculum. This process has made the findings authentic to be referred to and used by future researchers.

\section{RESULTS AND DISCUSSION}

The research findings were discovered to meet the needs of research questions. The discussion of the findings highlights that all experts agreed and stated that Fred Rogers' approach is an appropriate STEAM teaching strategy in preschools. This is because this approach pays attention to the teaching practice for children ranging from five to six years old [4]. This result was in line with [29] state that the learning style one of the main factors which influence the success of student achievement.

"In my opinion, this approach is very appropriate to use." (Expert 1, lines 136-141, 05/07/2018)

“In my opinion, this approach is appropriate..." (Expert 2, lines 98, 05/07/2018)

“Overall, Fred Rogers' approach is appropriate to use." (Expert 3, lines 138-140, $14 / 05 / 2018)$

"In my opinion, this approach is very appropriate to use." (Expert 4, lines 89-90, 08/05/2018) 
From the discussion with Expert 1, the approach is appropriate as it is seen to be parallel to children inquisitive characteristics which love to ask, seeking for reasons and consequences of certain physical changes and have the initiatives to creatively find the solutions to the problem. Besides, this approach fulfils the basic needs of those childeren who love to actively explore and investigate any situations that take place around them. Maison [30] also agreed that the natural exploration give the positive impact for student attitude to be more interest in learning process. This result was obtained from the interview with Expert 1:

"This approach is very relevant to the characteristics and needs of preschool students who love to make inquiries... Love to find out why...reasons and consequences of a situation..and seek for various solutions without feeling bored...” (Expert 1, lines 145-151, 05/07/2018)

Expert 2 was in a positive opinion of Fred Rogers' approach for the STEAM teaching activity. It is appropriate to be used by preschool teachers. This is because the approach applies inquiry-based learning that teaches children to be the effective constructor of STEAM knowledge and skills. Adding to that, inquirybased learning is one of the teaching strategies that is recommended in the National Preschools Standard Curriculum [17]. This inquiry-based learning allows students to naturally improve students' knowledge and skills of STEAM [30]. So as a teacher, they need to improve their pedagogical knowledge to be able to use this approach correctly and effectively with the student [31]. This finding is as based on the interview with Expert 2:

"Because it takes into account the learning that is based on inquiry...therefore it can effectively expose children to construct knowledge and skills related to STEAM." (Expert 2, lines 100-104, 05/07/2018)

Similarly, Expert 3 believed in the importance of applying this approach by teachers as STEAM teaching has been designed to equip students with knowledge, skills and values. The expert also recommended that this approach be executed holistically by teachers comprising three main activities which are designed to complement each other [4]. Activities like a conversation, scientific investigation and project are in line with the features of STEAM which are to construct knowledge and understanding of certain topics through investigations and explorations. This finding is as obtained from the interview with Expert 3:

"This is because its process comprises intended knowledge, skills and values which are to be mastered by students. The three main steps highlighted may allow students to master STEAM beginning from the early stage of school."

"To ensure students' ability in mastering STEAM elements, the approach used must be holistic according to the recommended phase. Suggested activities like a conversation, scientific investigation and project fulfil STEAM features." (Expert 3, lines 142-153, 14/05/2018)

The findings obtained from Expert 4 indicate that Fred Rogers' approach is in line with STEAM learning concepts which are based on inquiring and investigating activities. Therefore, this approach could positively expand students' knowledge and understanding through learning-by-doing activities or selfinvestigation. According to [32], the exposure of a suitable learning strategy to students can facilitate their process skills appropriately. This recommendation is reported as based on what has been shared by Expert 4:

"It is in line with the STEAM concept itself that its activities are based on questioning and investigating. This may expose the children to experiencing constructing their knowledge and understanding through "learning by" doing activities, through self-investigation." (Expert 4, lines 90-96, 08/05/2018)

Based on previous studies, some researchers have emphasized the good choice of teaching approach can improve children learning as well as increase their cognitive, socioemotional and creativity development [32-35]. However, the success of the learning process has come from the quality of teaching. This is in agreement with the report of the study suggest that Fred Rogers approach is effective teaching to develop STEAM skill among preschool children [4]. So, the teacher should enhance their 21st-century pedagogical knowledge and make a change to implement the Fred Rogers approach in the classroom [30]. By understanding that content, the teacher will be able to design and innovate teaching to attract children interest in STEAM learning and act as active learners [30, 31, 35]. The teachers will be more competent to deliver STEAM content with confidence and accuracy.

Int. J. Eval. \& Res. Educ. Vol. 9, No. 4, December 2020: 1071 - 1078 


\section{CONCLUSION}

Findings from the interviews revealed that all experts agreed on using Fred Rogers' approach as an appropriate STEAM teaching strategy to be practiced by teachers in preschools. These experts approved that this approach meets the features and fulfills the needs of STEAM Education at the preschool level. This is because STEAM concepts are learned by children through inquiring and investigating certain phenomena related to their everyday life. Hence, the result stresses that the actual STEAM skills are mastered when children become confident to inquire about anything and find out the solutions to any problems faced.

The uniqueness of this approach has convinced the experts that STEAM is practised by teachers through inquiry-based learning and learning-by-doing activities among preschool children. Teachers starts STEAM teaching with the children by inquiring certain topic or theme, followed by meeting the experts, video screening or sharing his experience visiting the children to help them explore a topic in depth. They also need to focus on the tools and materials used with children besides paying attention to what they ought to learn. Children are believed to be a genuine STEAM investigator who commits in terms of effort, feeling and experience towards the learning. Therefore, teachers' authenticity and care are essential in ensuring the success of generating future innovators.

So, now teachers should be able to develop their STEAM pedagogy knowledge to applying Fred Rogers' approach confidently. The execution of STEAM teaching using this approach which is begun with STEAM Language Conversation allows space for children to easily get exposure towards STEAM concepts. The teaching is expanded through STEAM investigation in the real world. The use of materials and technological tools are exposed optimally to create a meaningful learning ambiance for children. The last step requires children to be involved in a STEAM project. STEAM Project is a reinforcement activity related to STEAM knowledge which has been earlier obtained in steps one and two.

On the whole, experts collectively believed that this approach prioritises certain aspects like age, features, basic needs and abilities of children for each activity implementation. Experts also agreed that Fred Rogers' STEAM has been developed based on practices which are appropriate with children' development. This enables knowledge, values and skills to be instilled in children effectively.

\section{REFERENCES}

[1] Unit Pelaksanaan and Prestasi, "Malaysia education development plan 2013-2025: Annual report 2017 (in Malay)," Putrajaya: Kementerian Pendidikan Malaysia, 2017

[2] D.Dalton, STEAM white paper: planning for the plan. England. Chesterfield Country Public Schools. 2013.

[3] S.A.M Najib, H. Mahat and N.H. Baharudin, "The level of STEM knowledge, skills, and values among the students of bachelor's degree of education in geography," International Journal of Evaluation and Research in Education, vol. 9, no. 1, pp. 69-76, 2020.

[4] H. Sharapan, "From STEM to STEAM: how early children educators can apply Fred Rogers' Approach," Young Children, vol. 67, no. 1, pp. 36-40, 2012.

[5] L. Katz, "STEM in the early years," SEED Paper for Early Childhood Research and Practice, vol. 3, pp. 1-3, 2010.

[6] Z. Mengmeng, Y. Xiantong and W. Xinghua, "Construction of STEAM curriculum model and case design in Kindergarten," American Journal of Education Research, vol. 7, no. 7. pp. 485-490, 2019.

[7] L.C. Edwards, The creative arts: A process approach for teachers and children, (4th Ed.). Columbus, OH Merrill, 2006.

[8] D.A. Sousa and T. Pilecki, From STEM to STEAM: using brain-compatible strategies to integrate the arts. United Stated. SAGE Publication Ltd, 2013.

[9] E.W. Robelen, "Building STEAM: blending the arts with STEM subjects," Education Week, vol. 31, no. 13, pp. 8-9, 2011.

[10] A.T. Oner, et. al., "From STEM to STEAM: students' beliefs about the use of their creativity," The STEAM Journal, vol. 2, no. 2, pp. 1-14, 2016.

[11] J.M Piro, "Going from STEM to STEAM: the arts have a role in America's future too," Education Week, vol. 29, no. 24 , pp. 28-29, 2010.

[12] A.A. Akturk and H.O. Demircan, "A review of studies on STEM and STEAM Education in early childhood," Ahi Evran Universitesi Kirsehir Egitim Fakultesi Dergisi, vol. 18, no. 2, pp. 757-776, 2017.

[13] R. Schirrmacher, Art and creative development for young children. Clifton Park, NY: Thomson Delmar Learning, 2002.

[14] T. Wynn and J. Harris, "Toward a Stem + Arts curriculum: creating the teacher team," Journal Art Education, vol. 65, no. 5, pp. 42-47, 2012.

[15] K.W. Lindeman, M. Jabot, M. and M.T. Berkley, "The Role of STEM (or STEAM) in the Early Childhood Setting," in Learning Across the Early Childhood Curriculum Advances in Early Education and Day Care, vol. 17, pp. 95-114. Emerald Group Publishing Limited, 2014.

[16] A.M. Gordon and K.W. Browne, Beginnings and beyond: foundations in early childhood education [e-book], Cengage Learning, 2011.

[17] F. Rogers, The World according to Mr. Rogers: important things to remember. New York, NY: Hyperion, 2003. 
[18] Bahagian Pembangunan Kurikulum KPM. Kurikulum Standard Preschools Kebangsaan. Putrajaya. Kementerian Pendidikan Malaysia, 2016.

[19] Suraya, Norsalawati and Nasir, "Integration of STEM education in Malaysia and why to STEAM," International Journal of Academic Research in Business and Social Sciences, vol. 7, no. 6, pp. 645-654, 2017.

[20] D. Herro and C. Quigley, "Exploring teachers' perceptions of STEAM teaching through professional development: implications for teacher educators, Professional Development in Education," Professional Development in Education, vol. 43, no. 3, pp. 416-438, 2017.

[21] H. Park, et. al., "Teachers' perception and practices of STEAM Education in South Korea," Eurasia Journal of Mathematics, Science \& Technology Education, vol. 12, no. 7, pp. 1739-1753, 2016.

[22] F.M Jamil, S. M. Linder, and D. A, Stegelin, "Early childhood teacher beliefs about STEAM education after a professional development conference," Early Childhood Education Journal, vol. 46, no. 4, pp. 409-417, 2018.

[23] N.K. DeJarnette, "Implementing STEAM in the early childhood classroom," European Journal of STEM Education, vol. 3, no. 3, pp. 18-26, 2018.

[24] Y. Kim and N. Park, "Development and application of STEAM teaching model based on the Rube Goldberg's invention," in Yeo SS., Pan Y., Lee Y., Chang H. (eds), Computer science and its applications. Lecture Notes in Electrical Engineering, vol. 203, pp. 693-698. Springer, Dordrecht, 2012.

[25] J. Miller and G. Knezek, "STEAM for student engagement," In R. McBride \& M. Searson (Eds.), 2013 Proceedings of Society for Information Technology \& Teacher Education International Conference, pp. 3288-3298, 2013.

[26] K. Cook, et. al., "Development of elementary teachers' science, technology, engineering, arts and mathematics planning practices," Journal of Applied Social Psychology, vol. 120, no. 4, pp. 197-208, 2020.

[27] M.N. Yaakob, "Reka bentuk model kurikulum m-pembelajaran pengajian profesional di Institut Pendidikan Guru," Tesis Phd. Universiti Utara Malaysia, Kedah, 2017.

[28] M.B. Miles and A.M. Huberman, Qualitative data analysis, 2nd ed. Thousand Oks: Sage, 1994.

[29] N. Shamsuddin, and J. Kaur, "Students' learning style and its effects on blended learning, does it matter?" International Journal of Evaluation and Research in Education (IJERE), vol. 9, no. 1, pp. 195-202, 2020.

[30] M. Maison, et al., "Comparison of student attitudes towards natural sciences," International Journal of Evaluation and Research in Education (IJERE), vol. 9, no. 1, pp. 54-61, 2020.

[31] L. Maryani and S.T. Martaningsih, "Correlation between teacher's PCK (Pedagogical content knowledge) and student's motivation in primary school," International Journal of Evaluation and Research in Education (IJERE), vol. 4, no. 1, pp. 38-44, 2015.

[32] M.O. Servitri and W. Trisnawaty, "The development of inquiry science worksheet to facilitate the process skills," Journal of Education and Learning (EduLearn), vol. 12, no. 4, pp. 575-580, 2018.

[33] D.P. Edem, C. Dewodo., and P.B. Atiglah., "ICT skills, and benefits of teaching and learning animal science with blended learning at colleges of education in Ghana," Journal of Education and Learning (EduLearn), vol. 14, no. 2, pp. 289-300, 2020.

[34] G.H. Im, Y.K. Jiar and R. Talib, "Development of preschool social emotional inventory for preschoolers: a preliminary study," International Journal of Evaluation and Research in Education (IJERE), vol. 8, no. 1, pp. 158-164, 2019.

[35] Nooraida, et al., "The effect of coupled inquiry-5E in enhancing the understanding of Meiosis concept," International Journal of Evaluation and Research in Education (IJERE), vol. 9, no. 1, pp. 129-137, 2020. 